\title{
Comparison of the occurrence of tick-borne diseases in ticks collected from vegetation and animals in the same area1)
}

\author{
MONIKA ROCZEŃ-KARCZMARZ, PAULINA DUDKO*, MARTA DEMKOWSKA-KUTRZEPA, \\ MICHAŁ MEISNER ${ }^{\star *}$, MARIA STUDZIŃSKA, ANDRZEJ JUNKUSZEW*, \\ ANTONINA SOPIŃSKA***, KRZYSZTOF TOMCZUK
}

Department of Parasitology and Invasive Diseases, Faculty of Veterinary Medicine, University of Life Sciences in Lublin, Akademicka 12, 20-033 Lublin, Poland

*Sub-Department of Small Ruminant Breeding and Professor T. Efner Research Station,

Institute of Animal Breeding and Biodiversity Conservation, Faculty of Biology, Animal Science and Bioeconomy, University of Life Sciences in Lublin, Akademicka 13, 20-950 Lublin

**Department of Psychology, Faculty of Social Sciences,

The John Paul II Catholic University of Lublin, Al. Racławickie 14, 20-950 Lublin, Poland,

***Department of Fish Diseases and Biology, Faculty of Veterinary Medicine, University of Life Sciences in Lublin, Akademicka 12, 20-033 Lublin, Poland

Roczeń-Karczmarz M., Dudko P., Demkowska-Kutrzepa M., Meisner M., Studzińska M., Junkuszew A., Sopińska A., Tomczuk K.

Comparison of the occurrence of tick-borne diseases in ticks collected from vegetation and animals in the same area

Summary

The aim of this study was to compare the prevalence of selected pathogens in ticks taken from cats and dogs and from vegetation in urban settlements. A study was conducted to estimate the distribution of Anaplasma phagocytophilum and Borrelia burgdorferi in adult Ixodes ricinus (236), Dermacentor reticulatus (237) and Ixodes hexagonus (3) ticks collected from animals in veterinary clinics (184) and from vegetation in urban settlements (292). The most numerous ticks collected from animals were Ixodes ricinus (73.9\%), followed by Dermacentor reticulatus (24.5\%) and Ixodes hexagonus (1.6\%). A total of $65.8 \%$ of the ticks collected from vegetation were Dermacentor reticulatus and $30 \%$ were Ixodes ricinus. The arthropods removed from the animals were most commonly located around the neck (48.1\%) and in the mouth area (17.1\%). All ticks were analyzed by molecular techniques. The percentages of ticks positive for Borrelia burgdorferi and Anaplasma phagocytophilum among those collected from animals differed from the corresponding rates for ticks taken from vegetation in the same area. Anaplasma phagocytophilum was more common in ticks collected from vegetation $(\mathrm{N}=137$, or $47.20 \%)$ than in those from animals $(\mathrm{N}=12$, or $6.6 \%)$. Borrelia burgdorferi, as well, was more common in ticks collected from the vegetation $(\mathrm{N}=96$, or $32.9 \%)$ than in those from animals $(\mathrm{N}=19$, or $10.5 \%)$. The DNA of A. phagocytophilum and B. burgdorferi were detected in $30.4 \%$ and $22.8 \%$ of D. reticulatus ticks, respectively, and in $32.6 \%$ and $25.4 \%$ of I. ricinus ticks, respectively. The DNA of A. phagocytophilum was also found in one Ixodes hexagonus tick. Single infections were noted in 69 I. ricinus ticks, 56 D. reticulatus ticks and 1 I. hexagonus tick. Coinfections of A. phagocytophilum with B. burgdorferi were detected in 33 (14.0\%) I. ricinus ticks and in $29(12.24 \%)$ D. reticulatus ticks. Infected companion animals can form a reservoir for human tick-transmitted infectious agents. The monitoring of the pathogens transmitted by ticks is an important tool in preventing and combating infections transmitted to humans and animals.

Keywords: Ixodes ricinus, Dermacentor reticulatus, Ixodes hexagonus, Anaplasma phagocytophilum, Borrelia burgdorferi, pets

1) The study was conducted under the project „The uses and protection of the genetic resources of farm animals under conditions of sustainable development” co-financed by the National Centre for Research and Development as part of the strategic programme of research and development „Natural environment, agricultre and forestry" - BIOSTRATEG. 
Ticks, as hematophages, are a disease transmission vector for both humans and animals. They play an important role in the natural transmission of disease and in transferring pathogens between hosts. The spread of ticks is favoured by a number of ecological, physiological and molecular features. These include high adaptability to changing environmental conditions, climate, the large number of host species, population density in a given area, and the ability to transmit pathogens transovarially (from one generation to the next via the female ovaries) and trans-stadially (from stage to stage: from larvae to nymphs and to adults). The migration of the hosts to geographically distant areas thus aids the spread of ticks and the pathogens transmitted by them $(29,44)$. The pathogens most often occur in forest ecosystems, in wild animals that constitute a natural source of infection. Ticks are carried away from their natural environment due to the migration of their hosts on which they parasitize, the development of tourism, and frequent trips of the owners of companion animals. In this way, the spread of ticks into new territories contributes to the appearance of new disease entities in areas where they had not previously occurred $(42,36)$.

In Poland, the most numerous ticks are those from the genus Ixodes: Ixodes ricinus and Dermacentor reticulatus. The former is one of the most important arthropods in the epidemiology of transmission diseases and is considered the most important tick vector in Europe. In Poland, the pathogens most frequently transmitted by $I$. ricinus ticks are Borrelia burgdorferi s.l. and Anaplasma phagocytophilum, protozoa from the genus Babesia and the tick-borne encephalitis virus (KZM) (Flaviviridae) $(47,54,53)$. D. reticulatus is the second most important vector of many transmissible diseases, and the pathogens most frequently transmitted by these ticks are Babesia spp., Borrelia burgdorferi s.l., Anaplasma marginale, Rickettsia spp., and the tick-borne encephalitis virus (KZM) (Flaviviridae) (4, 21, 46). Ixodes hexagonus is rarely found in Poland, probably because it is a typically a nest-dwelling species. This tick is involved in the transmission of pathogens that are dangerous to humans and animals, including tickborne encephalitis, Borrelia spp., Rickettsia spp., and Anaplasma phagocytophilum $(23,29,40)$.

Pathogens transmitted by ticks are an important problem in both human and veterinary medicine, with tick-borne diseases being a major threat for humans and animals. The aim of this study was to determine the prevalence of selected pathogens in ticks collected from cats and dogs living in urban habitats and from vegetation in urban settlements.

\section{Material and methods}

Study area and tick collection. The study was conducted in south-eastern Poland in the years 2015-2017. The study included 476 ticks (Ixodes ricinus, Dermacentor reticulatus and Ixodes hexagonus), (Acari: Ixodidae). The ticks were examined in two groups: those collected from the environment and those found on animals brought into the veterinary clinics. Ticks originating from the environment were collected during the spring and autumn periods of their activity. They were collected by the flagging method from typically urban areas highly frequented by animals and their owners, such as walking routes and city parks. Grass, shrubs and bushes (up to $1.5 \mathrm{~m}$ in height) were swept with a white flannel flag $(1 \times 1 \mathrm{~m})$. The material collected was preserved in plastic sample-tubes. The second group of ticks were collected from cats and dogs (each tick came from a different animal) in several veterinary clinics in Lublin. The parasites were removed from animals with tweezers, described (cat/dog host, age, sex, breed, and location on the host) and placed in an Eppendorf tube. In the laboratory, all ticks were placed in $70 \%$ ethyl alcohol. Next, the developmental stage, genus and species of each tick were determined (43) using the Cell light microscope system software from Olympus and then preserved for further molecular studies.

DNA isolation and detection of Anaplasma phagocytophilum and Borrelia burgdorferi. DNA was isolated from 476 Ixodes ricinus, Dermacentor reticulatus, and Ixodes hexagonus ticks collected from vegetation (292) and from cats and dogs (184). The ticks were removed from ethanol storage and crushed. DNA isolation was performed using a Genomic Mini kit (A\&A Biotechnology, Poland), according to the manufacturer's instructions.

Polymerase Chain Reaction (PCR). PCR reactions were carried out to test for the presence of Borrelia burgdorferi and Anaplasma phagocytophilum. The amplifications were performed using an MJ Research PTC-200 DNA Engine (BioRad, USA). Each PCR reaction was carried out in a $25 \mu \mathrm{l}$ reaction volume containing $12.5 \mu \mathrm{l}$ of DreamTaq Green PCR Master Mix (ThermoFisher Scientific, USA), $0.6 \mu 1$ of $10 \mu \mathrm{M}$ each of primer (DNA Sequencing and Synthesis Service of the Institute of Biochemistry and Biophysics, Polish Academy of Sciences in Warsaw, Poland.), $3 \mu 1$ of matrix DNA and $8.3 \mu 1$ of nuclease-free water supplied for the PCR Master Mix.

Detection of Borrelia burgdorferi was carried out using the primers FL6 5'-TTCAGGGTCTCAAGCGTCTTGGACT-3' and FL7 5'-GCATTTTCAATTTTAGCAAGTGATG-3', which amplify a product of $276 \mathrm{bp}$ for sequencing the flagellin flaB gene (35). The reactions were performed under the following conditions: initial denaturation at $94^{\circ} \mathrm{C}$ for 2 minutes, followed by 30 cycles of denaturation at $94^{\circ} \mathrm{C}$ for 1 minute, annealing at $37^{\circ} \mathrm{C}$ for 2 minutes, extension at $72^{\circ} \mathrm{C}$ for $3 \mathrm{~min}-$ utes, followed by a final extension at $72{ }^{\circ} \mathrm{C}$ for 3 minutes.

To identify Anaplasma phagocytophilum, the following primers were used: EHR 521: 5'-TGTAGGCGGTTCGGTAAGTTAAAG-3' and EHR 747: 5'-GCACTCATCGTTTACAGCGTG-3', which amplify a product of $274 \mathrm{bp}$ for the 16S rRNA gene (54). The reactions were performed under the following conditions: initial denaturation at $94^{\circ} \mathrm{C}$ for 5 minutes, followed by 40 cycles with denaturation at $94^{\circ} \mathrm{C}$ for 45 seconds, annealing at $37^{\circ} \mathrm{C}$ for 45 seconds, extension at $72^{\circ} \mathrm{C}$ for 45 seconds, and final extension at $72^{\circ} \mathrm{C}$ for 5 minutes.

The PCR products were subjected to electrophoresis in $2 \%$ agarose gels for the detection of A. phagocytophilum and in $1 \%$ agarose gels for $B$. burgdorferi; the gels were stained with ethidium bromide and visualized under ultraviolet light.

Statistical analysis. The statistical analysis of parasite occurrence related to the environmental origin involved a chisquare test (including the results of the Z Fisher test with Bonferroni correction for significance level) and two types of nominal correlation depending on the number of categories of the variables (V Cramer and Phi). All analyses were performed using the PS Imago software package (IBM SPSS 
Statistics Version 23). The chi-square test and the Z Fisher test were used for precise determination of statistically significant differences between the presence of each parasite associated with an independent variable - the environment. Cramer's phi correlation was used to demonstrate a relationship between the variables and their strength. A $p$ value of $\leq 0.05$ was considered significant.

\section{Results and discussion}

The detection of pathogens in ticks, as definitive hosts, and in animals, as intermediate hosts, is an important tool in understanding the transmission of pathogens in nature. In this study we analyzed Ixodes ricinus, Dermacentor reticulatus and Ixodes hexagonus ticks for the presence of Borrelia burgdorferi and Anaplasma phagocytophilum.

Overall, a total of 476 ticks were collected, 184 of which originated from animals ( 65 from dogs, 119 from cats) and 292 from vegetation. There are statistically significant differences in the numbers of Dermacentor reticulatus $(\mathrm{n}=45)$ and Ixodes ricinus $(\mathrm{n}=136)$ collected from the animals $\left(\mathrm{Chi}^{2}=45.75, \mathrm{df}=1, \mathrm{p}<0.001\right)$. Our studies show that the most common ticks in the animals were Ixodes ricinus $(73.9 \%)$, followed by Dermacentor reticulatus (24.5\%) and Ixodes hexagonus $(1.6 \%)$. With regard to the ticks collected from vegetation, $65.8 \%$ were Dermacentor reticulatus and 30\% were Ixodes ricinus. Most of the ticks removed from animals were located in the neck area $(48.1 \%)$. Ticks were also removed from the area of the mouth $(17.1 \%)$, paws $(14.9 \%)$, abdomen $(10.5 \%)$ and back $(9.4 \%)$. The high proportion of ticks found on the head is confirmed by other studies (6).

There are statistically significant differences in the occurrence of Anaplasma phagocytophilum $\left(\mathrm{Chi}^{2}=\right.$ 84.99, $\mathrm{df}=1, \mathrm{p}<0.001$ ) and Borrelia burgdorferi $\left(\mathrm{Chi}^{2}=30.41\right.$, df $=1$, $p<0.001$ ) depending on the origin of the ticks. Anaplasma phagocytophilum was more common in ticks originating from vegetation $(\mathrm{n}=137$, or $47.20 \%$ ) than in those from animals $(\mathrm{n}=12$, or $6.6 \%)$. Anaplasma phagocytophilum was found in one Ixodes hexagonus tick, but due to the low numbers of this tick, the results were not taken into account in statistical calculations. Borrelia burgdorferi was more common in ticks from the vegetation $(\mathrm{n}=96$, or $32.9 \%$ ) than in ticks from animals ( $\mathrm{n}=19$, or $10.5 \%$ ).

Single infections were noted in 69 I. ricinus, in 56 D. reticulatus and in 1 I. hexagonus ticks. Coinfections of Anaplasma phagocytophilum with Borrelia burgdorferi were detected in $33(14.0 \%)$ Ixodes ricinus ticks and in 29 (12.24\%) Dermacentor reticulatus ticks. The prevalence of $A$. phagocytophilum and $B$. burgdorferi in adult $I$. ricinus, $D$. reticulatus and I. hexagonus ticks collected from animals and vegetation is shown in Table 1.

I. ricinus is widespread in Poland, and its numbers are steadily growing (Siuda et al. 1995). The risk of infestation with $D$. reticulatus is also high in the study area, because eastern and central Poland is inhabited by populations of this tick $(21,22)$. Recreational areas in Poland abound in $I$. ricinus $(1,50,51,55)$, and to a lesser extent in $D$. reticulatus $(3,24,55)$. Both $I$. ricinus $(10$, $12,20,49)$ and $D$. reticulatus ticks $(19,19,32)$ can be found in Europe.

In our study, the majority of ticks collected from walking areas in the Lublin districts belonged to the $D$. reticulatus species, while the ticks collected from animals were mostly from the I. ricinus species. Very similar results for ticks collected from pets were obtained in other studies in Poland (24) and in Belgium (6). Other authors in Poland $(27,57)$ found the largest number of $D$. reticulatus ticks on animals, especially dogs. Both species differ in terms of geographic range, seasonal and daily activity peaks and type of habitat $(15,17$, $30)$. Nevertheless, both species occur in most housing estates and walking routes in the Lublin region. Most I. ricinus were collected in alleys and housing estates, places where short vegetation passes into dense shrubs

Tab. 1. Prevalence of Anaplasma phagocytophilum and Borrelia burgdorferi in adult Ixodes ricinus, Dermacentro reticulatus and Ixodes hexagonus ticks collected from animals in urban areas

\begin{tabular}{|l|l|c|c|c|}
\hline Location of tick collection & \multicolumn{1}{|c|}{ Pathogen } & D. reticulatus & I. ricinus & I. hexagonus \\
\hline \multirow{2}{*}{ Vegetation } & B. burgdorferi & 51 & 44 & 0 \\
& A. phagocytophilum & 72 & 65 & 0 \\
Cats & B. burgdorferi & 2 & 6 & 0 \\
& A. phagocytophilum & 0 & 6 & 0 \\
\multirow{3}{*}{ Dogs } & B. burgdorferi & 1 & 10 & 0 \\
& A. phagocytophilum & 0 & 6 & 1 \\
\hline
\end{tabular}

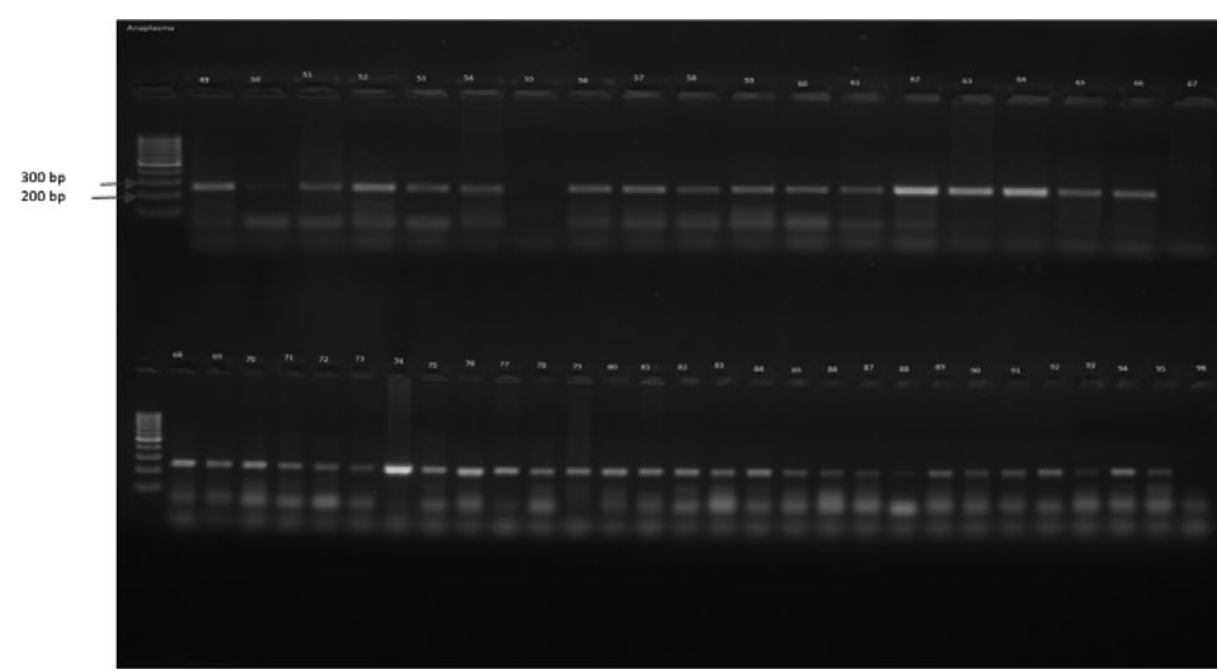

Fig. 1. Gel electrophoresis of PCR products in a 2\% agarose gel using Anaplasma phagocytophilum specific 16S rRNA gene region primers (274 pb PCR product). Lines from 49 to 58 - D. reticulatus, and from 59 to $70-$ I. ricinus 
and trees. Also, tall uncropped grass favoured the occurrence of $I$. ricinus. The vicinity of the Bystrzyca River and the Zemborzycki Reservoir favoured the occurrence of $D$. reticulatus. In our study, out of 184 ticks collected from animals, only 3 were I. hexagonus. In Europe, ticks of this species are most often found on hedgehogs $(8$, $11,34)$, but they are also found on companion animals $(24,27,28,31,45)$.

The main vector of $A$. phagocytophilum is the I. ricinus tick. The literature mentions few cases of $A$. phagocytophilum transmission by $D$. reticulatus $(22,52,56)$. Our study indicates a high risk of Anaplasma phagocytophilum and Borrelia burgdorferi in the study areas. This study showed high rates of $A$. phagocytophilum infection in $D$. reticulatus and $I$. ricinus ticks. The percentages of $I$. ricinus ticks infected with $A$. phagocytophilum and B. burgdorferi were very high: $32.6 \%$ and $25.4 \%$, respectively. Ixodes ricinus was within the range of infections with Borrelia (3.1-40.0\%) and Anaplasma $(1.0-35.0 \%)$ in other European countries $(5,6,10)$, although in Poland our results indicate the highest level for Borrelia (5.6-23.5\%) and Anaplasma (1.7-19.1\%) $(9,13,24,39,48,51)$ in urban areas and on walking paths. Anaplasma phagocytophilum is found rarely in $D$. reticulatus ticks in Poland and other European countries (1.1-25.36\%) $(22,56)$, whereas B. burgdorferi occurs more often and with lower infection rates (0.6$-2.7 \%)(9,24,37)$. In our study, D. reticulatus ticks were highly infected with $A$. phagocytophilum (30.4\%) and $B$. burgdorferi (22.8\%). Our study shows that A. phagocytophilum in D. reticulatus ticks occurred only in specimens collected from vegetation, and that the rates of infection with both pathogens for I. ricinus and $D$. reticulatus ticks were at a similar, high level. This may result from the fact that the primary source of infection occurs in urban settlements, where infected intermediate hosts are likely to occur.

The percentages of ticks collected from animals and positive for Borrelia burgdorferi and Anaplasma phagocytophilum were $10.5 \%$ and $6.6 \%$, respectively. These rates were within the range of infection for Borrelia $(0.3-22.5 \%)$ and Anaplasma (1.6-19.5\%) found in other European countries $(2,6,24,28,57)$.

The presence of $B$. burgdorferi and A. phagocytophilum in ticks can be determined by the activity of the ticks' hosts inhabiting the biotope, whose occurrence is influenced by a multiple of biotic and abiotic factors $(14,26,41)$. The reservoir hosts for $B$. burgdorferi in urban settings are rodents, hedgehogs, foxes, squirrels, hares, birds and deer $(14,16,25,38)$. The typical reservoir hosts for $A$. phagocytophilum are red deer, roe deer, bank voles and wood mice $(21,52)$. The natural hosts for I. ricinus, which are found in forests (Cervidae, Carnivores), most probably also act as reservoirs for A. phagocytophilum (51). However, the role of pets should also be taken into account. The development of settlements and their expansion into wasteland, in the vicinity of forests and rivers, increases the access to vectors. Economic and civilizational development often takes place at the expense of the natural environment. Many species of animals settle and increase in numbers in an uncontrolled manner (7).

There was no significant difference between I. ricinus and $D$. reticulatus in the proportion of ticks that contained DNA from both pathogens. All multiple infections were detected in adult $I$. ricinus and D. reticulatus ticks, suggesting that they may have fed on the same reservoir hosts. The study of the frequency of coinfection in ticks in a specific area can be used as a tool to help diagnose diseases in humans and animals. In our study, the frequency of coinfection with $A$. phagocytophilum and B. burgdorferi was high in both I. ricinus and $D$. reticulatus. Other authors have also observed the coincidence of B. burgdorferi with A. phagocytophilum $(33,54)$. Such results show that there is a high risk of simultaneous transmission of both pathogens during a single tick bite.

This study shows that there is a high risk of contracting Lyme disease and anaplasmosis in the urban environment, which poses a threat to human and animal populations. It has been shown that, next to I. ricinus, $D$. reticulatus is the second most important vector involved in the transfer of $A$. phagocytophilum. Inhabitants and health professionals in cities should be more aware of the risk of Lyme disease and anaplasmosis in green areas or other recreational areas where infected ticks occur.

\section{References}

1. Asman M., Solarz K., Cuber P., Gąsior T., Szilman P., Szilman E., Tondaś E. MatzullokA., Kusion N., Florek K.: Detection of protozoans Babesia microti and Toxoplasma gondii and their co-existence in ticks collected in Tarnogórski district. Ann. Agric. Environ. Med. 2015, 22, 50-83, doi: 10.5604/12321966.1141373.

2. Beichel E., Petney T. N., Hassler D., Brückner M., Maiwald M.: Tick infestation patterns and prevalence of Borrelia burgdorferi in ticks collected at a veterinary clinic in Germany. Vet. Parasitol. 1996, 65, 147-155. 10.1016/03044017(96)00943-0.

3. Biernat B., Karbowiak G., Werszko J., Stańczak J.: Prevalence of tick-borne encephalitis virus (TBEV) RNA in Dermacentor reticulatus ticks from natural and urban environment, Poland. Exp. Appl. Acarol. 2014, 64, 543-551. doi: 10.1007/s10493-014-9836-5.

4. Bonnet $S$, de la Fuente $J$., Nicollet P., Liu X., Madani N., Blanchard B., Maingourd G., Alongi A., Torina A., Fernández de Mera I. G., Vicente J., George J. C., Vayssier-Taussat M., Joncour G.: Prevalence of tick-borne pathogens in adult Dermacentor spp. ticks from nine collection sites in France. Vector-Borne Zoonotic Dis. 2013, 13, 226-236.

5. Christova I., Van De Pol J., Yazar S.: Identification of Borrelia burgdorferi sensu lato, Anaplasma and Ehrlichia species, and spotted fever group rickettsiae in ticks from Southeastern Europe. Eur. J. Clin. Microbiol. Infect. Dis. 2003, 22, 535-542.

6. Claerebout E., Losson B., Cochez C., Casaert S., Dalemans A. C., De Cat A. Madder M., Saegerman C., Heyman P., Lempereur L.: Ticks and associated pathogens collected from dogs and cats in Belgium. Parasit. Vectors 2013, 19, 6, 183. doi: 10.1186/1756-3305-6-183.

7. Dudek K., Jerzak L., Tryjanowski P.: Zwierzęta konfliktowe w miastach. Regionalna Dyrekcja Ochrony Środowiska w Gorzowie Wielkopolskim 2016, p. 1-243.

8.Dziemian S., Michalik J., Piłacińska B., Bialik S., Sikora B., Zwolak R.: Infestation of urban populations of the Northern white-breasted hedgehog, Erinaceus roumanicus, by Ixodes spp. ticks in Poland. Med. Vet. Entomol. 2014, 28, 465-469. doi: 10.1111/mve.12065.

9. Dziegiel B., Kubrak T., Adaszek E., Debiak P., Wyłupek D., Bogucka-Kocka A., Lechowski J., Winiarczyk S.: Prevalence of Babesia canis Borrelia burgdorferi sensu lato and Anaplasma phagocytophilum in hard ticks collected from meadows of Lubelskie Voivodship (eastern Poland). Bull. Vet. Inst. Pulawy 2014, 58, 29-33.

10. Franke J., Hildebrandt A., Meier F., Straube E., Dorn W.: Prevalence of Lyme disease agents and several emerging pathogens in questing ticks from the German Baltic coast. J. Med. Entomol. 2011, 48, 441-444. DOI: 10.1603/ME10182 
11. Gern L., Rouvinez E., Toutoungi L. N., Godfroid E.: Transmission cycles of Borrelia burgdorferi sensu lato involving Ixodes ricinus and/or I. hexagonus ticks and the European hedgehog, Erinaceus europaeus, in suburban and urban areas in Switzerland. Folia Parasitol. 1997, 44, 309-314.

12. Gray J. S., Kirstein F., Robertson J. N., Stein J., Kahl O.: Borrelia burgdorferi sensu lato in Ixodes ricinus ticks and rodents in a Recreational Park in SouthWestern Ireland. Exp. Appl. Acarol. 1999, 23, 717-729.

13. Grzeszczuk A., Stanczak J., Kubica-Biernat B.: Serological and molecular evidence of human granulocytic ehrlichiosis focus in the Bialowieza Primeve Forest, northeastern Poland. Eur. J. Clin. Microbiol. Infect. Dis. 2002, 21, 6-11.

14. Grzeszczuk A., Ziarko S., Kovalchuk O., Stańczak J.: Etiology of tick-borne febrile illnesses in adult residents of North-Eastern Poland: report from a prospective clinical study. Internat. J. Med. Microbiol. 2006, 296, 242-249.

15. Guglielmone A. A., Robbins R. G., Apanaskevich D. A., Petney T. N., EstradaPeña A., Horak I.: The hard ticks of the world. Springer, Dordrecht 2014, p. 635

16. Hamer S. A., Tsao J. I., Walker E. D., Mansfield L. S., Foster E. S., MS, Hickling $G$. J.: Use of tick surveys and serosurveys to evaluate pet dogs as a sentinel species for emerging Lyme disease. Am. J. Vet. Res. 2009, 70, 49-56. doi. org/10.2460/ajvr.70.1.49

17. Hillyard P. D.: Ticks of North-West Europe. The Natural History Museum, London 1996, p. 178

18. Hornok S., Kartali K., Takács N., Hofmann-Lehmann R.: Uneven seasonal distribution of Babesia canis and its two 18S rDNA genotypes in questing Dermacentor reticulatus ticks in urban habitats. Ticks Tick Borne Dis. 2016, 7 , 694-697. doi: 10.1016/j.ttbdis.2016.02.016.

19. Hornok S., Meli M. L., Gönczi E., Halász E., Takács N., Farkas R., HofmannLehmann R.: Occurrence of ticks and prevalence of Anaplasma phagocytophilum and Borrelia burgdorferi s.l. in three types of urban biotopes: forests, parks and cemeteries. Ticks Tick Borne Dis. 2014, 5, 785-789. doi: 10.1016/ j.ttbdis.2014.05.010.

20. Junttila J., Peltomaa M., Soini H., Marjamäki M., Viljanen M. K.: Prevalence of Borrelia burgdorferi in Ixodes ricinus Ticks in Urban Recreational Areas of Helsinki. J. Clin. Microbiol. 1999, 37, 1361-1365.

21. Karbowiak G.: Kleszcz łąkowy Dermacentor reticulatus - wystepowanie, biologia i rola jako wektora chorób odkleszczowych. Rozprawa habilitacyjna. Agencja Reklamowo-Wydawnicza A. Grzegorczyk, Warszawa 2009.

22. Karbowiak G., Vichová B., Slivinska K., Werszko J., DidykJ.,Pet'ko B., Stanko M. Akimov I.: The infection of questing Dermacentor reticulatus ticks with Babesia canis and Anaplasma phagocytophilum in the Chernobyl exclusion zone. Vet. Parasitol. 2014, 204, 372-375. doi: 10.1016/j.vetpar.2014.05.030.

23. Krivanec K., Kopecky E., Tomkova E., Grubhoffer L.: Isolation of the TBE virus from the tick Ixodes hexagonus, Folia Parasitol. Praha 1998, 273-276.

24. Król N., Kiewra D., Szymanowski M., Lonc E.: The role of domestic dogs and cats in the zoonotic cycles of ticks and pathogens. Preliminary studies in the Wrocław Agglomeration (SW Poland). Vet. Parasitol. 2015, 30, 214, 208-212. doi: 10.1016/j.vetpar.2015.09.028

25. Margos G., Vollmer S. A., Cornet M., Garnier M., Fingerle B., Wilske B., Bormane A., Vitorino L., Collares-Periera M., Drancourt M., Kurtenbach K. MLSA on housekeeping genes defines a new Borrelia species. Appl. Environ. Microbiol. 2009, 75, 5410-5416.

26. Michalik J., Hofman T., Buczek A., Skoracki M., Sikora B.: Borrelia burgdorferi s.l. in Ixodes ricinus (Acari: Ixodidae) Ticks Collected from Vegetation and Small Rodents in Recreational Areas of the City of Poznań. J. Med. Entomol. 2003, 40, 690-697.

27. Mierzejewska E. J., Welc-Faleciak R., Karbowiak G., Kowalec M., Behnke J. M., Bajer A.: Dominance of Dermacentor reticulatus over Ixodes ricinus (Ixodidae) on livestock, companion animals and wild ruminants in eastern and central Poland. Exp. Appl. Acarol. 2015, 66, 83-101. doi: 10.1007/s10493-015-9889-0.

28. Nijhof A. M., Bodaan C., Postigo M., Nieuwenhuijs H., Opsteegh M., Franssen L., Jebbink $F$., Jongejan F.: Ticks and associated pathogens collected from domestic animals in the Netherlands. Vector Borne Zoonotic Dis. 2007, 7, 1-11. 10.1089/ vbz.2007.9999.

29. Nowak-Chmura M.: Fauna kleszczy (Ixodida) Europy Środkowej. Wydawnictwo Naukowe UP, Kraków 2013, s. 212.

30. Nowak-Chmura M., Siuda K.: Ticks of Poland. Review of contemporary issues and latest research. Ann. Parasitol. 2012, 58, 125-155.

31. Ogden N. H., Cripps P., Davison C. C., Owen G., Parry J. M., Timms B. J., Forbes A. B.: The ixodid tick species attaching to domestic dogs and cats in Great Britain and Ireland. Med. Vet. Entomol. 2000, 14, 332-338. doi: 10.1046/j.13652915.2000.00244.x.

32. Olivieri E., Gazzonis A. L., Zanzani S. A., Veronesi F., Manfredi M. T. Seasonal dynamics of adult Dermacentor reticulatus in a peri-urban park in southern Europe. Ticks Tick Borne Dis. 2017, 8, 772-779. doi: 10.1016 j.ttbdis.2017.06.002.

33. PanczukA., Tokarska-Rodak M., Koziol-Montewka M., PlewikD.: The incidence of Borrelia burgdorferi, Anaplasma phagocytophilum and Babesia microti coinfections among foresters and farmers in eastern Poland. J. Vector Borne Dis. 2016, 53, 348-354

34. Pfäffle M., Petney T., Skuballa J., Taraschewski H.: Comparative population dynamics of a generalist (Ixodes ricinus) and specialist tick (I. hexagonus) species from European hedgehogs. Exp. Appl. Acarol. 2011, 54, 151-164. doi: 10.1007/s10493-011-9432-x.
35. Picken R.: Polymerase chain reaction primers and probes derived from flagellin gene sequences for specific detection of the agents of Lyme disease and North American relapsing fever. J. Clin. Microbiol. 1992, 30, 99-114.

36. Płoneczka K., Rypuła K., Karczmarczyk R., Szenborn L., Stańczak J.: Badania kleszczy w kierunku zakażenia Ehrlichia canis z zastosowaniem reakcji PCR. Med. Weter. 2006, 62, 553-556.

37. Reye A. L., Stegniy V., Mishaeva N. P., Velhin S., Hübschen J. M., Ignatyev G., Muller C. P.: Prevalence of tick-borne pathogens in Ixodes ricinus and Dermacentor reticulatus ticks from different geographical locations in Belarus. PLOS ONE 2013, 8, e54476.

38. Rizzoli R., Stevenson J. C., Bauer J. M., van Loon L. J., Walrand S., Kanis J. A., Cooper C., Brandi M. L., Diez-Perez A., Reginster J. Y.: The role of dietary protein and vitamin $\mathrm{D}$ in maintaining musculoskeletal health in postmenopausal women: a consensus statement from the European Society for Clinical and Economic Aspects of Osteoporosis and Osteoarthritis (ESCEO). Maturitas. 2014, 79, 9, 122-132. doi: 10.1016/j.maturitas.2014.07.005.

39. Roczeń-Karczmarz M.: Zintegrowane działanie pyretroidów na Dermacentor reticulatus (Fabricius, 1794) (Acari: Ixodida: Ixodidae) zebrane we wschodniej Polsce na terenach chronionych o dużym ryzyku zakażenia krętkami Borrelia burgdorferi s.1.”. 2009. Doctoral dissertation, Faculty of Medicine with the Dental Department, Medical University of Lublin, Lublin 2009.

40. Schreiber C., Krücken J., Beck S., Maaz D., Pachnicke S., Krieger K., Gross M., Kohn B., von Samson-Himmelstjerna G.: Pathogens in ticks collected from dogs in Berlin/Brandenburg, Germany. Parasit Vectors. 2014, 7, doi: 10.1186 s13071-014-0535-1.

41. Siński E., Pawetczyk A., Bajer A., Behnke J.: Abundance of wild rodents, ticks and environmental risk of Lyme borreliosis: a longitudinal study in an area of Mazury Lakes district of Poland. Ann. Agric. Environ. Med. 2006, 13, 295-300.

42. Siński E., Welc-Falęciak R.: Risk of infections transmitted by ticks in forest ecosystems of Poland. Zarządzanie Ochrona Przyrody w Lasach 2012, tom VI.

43. Siuda K.: Kleszcze Polski (Acari: Ixodidae), cz. II. Systematyka i rozmieszczenie. Monografie Parazytol. nr 12, Wyd. Pol. Tow. Parazyt., Warszawa 1993.

44. Siuda K.: The review of data of the distribution of Ixodida (Acari) in Poland [in:] Kropczyńska D., Boczek J., Tomczyk A. (eds): The Acari, physiological and ecological aspects of Acari-host relationships. Dabor, Warszawa 1995, 273-280.

45. Smith F. D., Ballantyne R., Morgan E. R., Wall R.: Prevalence, distribution and risk associated with tick infestation of dogs in Great Britain. Med. Vet. Entomol. 2011, 25, 377-384 doi: 10.1111/j.1365-2915.2011.00954.x.

46. Stańczak J.: Detection of spotted fever group (SFG) rickettsiae in Dermacentor reticulatus (Acari: Ixodidae) in Poland. Int. J. Med. Microbiol. 2006, 296, 40, 144-148.

47. Stańczak J., Gabre R. M., Kruminis-Łozowska W., Racewicz M., Kubica B. Ixodes ricinus as a vector of Borrelia burgdorferi sensu lato, Anaplasma phagocytophilum and Babesia microti in urban and suburban forests. Ann. Agric. Environ. Med. 2004, 11, 109-114.

48. Stańczak J., Kubica-Biernat B., Racewicz M., Kruminis-Eozowska W., Kur J. Detection of three genospecies of Borrelia burgdorferi sensu lato in Ixodes ricinus ticks collected in different regions of Poland. Int. J. Med. Microbiol. 2000, 290, 559-566.

49. Svitálková Z., Haruštiaková D., Mahriková L., Berthová L., Slovák M., Kocianová E., Kazimírová $M$ :: Anaplasma phagocytophilum prevalence in ticks and rodents in an urban and natural habitat in South-Western Slovakia. Parasit. Vectors 2015, 8, 276 doi: 10.1186/s13071-015-0880-8.

50. Wegner Z., Racewicz M., Kubica-Biernat B., Kruminis-Łozowska W., StańczakJ. Występowanie kleszczy Ixodes ricinus (Acari, Ixodidae) na zalesionych obszarach Trójmiasta i ich zakażenie krętkami Borrelia burgdorferi. Przegl. Epidemiol. 1997, 51, 11-20

51. Welc-Falęciak R., Kowalec M., Karbowiak G., Bajer A., Behnke M. J., Siński E. Rickettsiaceae and Anaplasmataceae infections in Ixodes ricinus ticks from urban and natural forested areas of Poland. Parasites \& Vectors 2014, 7, 121. DOI: dx.doi.org/10.1186/1756-. 3305-7-121.

52. Wirtgen M., Nahayo A., Linden A., Garigliany M., Desmechtl D.: Detection of Anaplasma phagocytophilum in Dermacentor reticulatusticks. Vet. Rec. 2011, $168,195$.

53. Wójcik-Fatla A., Cisak E., Zając V., Zwoliński J., Dutkiewicz J.: Prevalence of tick-borne encephalitis virus in Ixodes ricinus and Dermacentor reticulatus ticks collected from the Lublin region (eastern Poland). Ticks Tick Borne Dis. 2011, 2, 16-19. doi: 10.1016/j.ttbdis.2010.10.001.

54. Wójcik-Fatla A., Szymańska J., Wdowiak L., Buczek A., Dutkiewicz J.: Coincidence of three pathogens (Borrelia burgdorferi sensu lato, Anaplasma phagocytophilum and Babesia microti) in Ixodes ricinus ticks in the Lublin macroregion. Ann. Agric. Environ. Med. 2009, 16, 151-158.

55. Wójcik-Fatla A., Zając V., Sawczyn A., Cisak E., Dutkiewicz J.: Babesia spp. in questing ticks from eastern Poland: prevalence and species diversity. Parasitol. Res. 2015, 114, 3111-3116. doi: 10.1007/s00436-015-4529-5.

56. Zając V., Wójcik-Fatla A., Sawczyn A., Cisak E., Sroka J., Kloc A., Zając Z., BuczekA., Dutkiewicz J., Bartosik K.: Prevalence of infections and co-infections with 6 pathogens in Dermacentor reticulatus ticks collected in eastern Poland. Ann. Agric. Environ. Med. 2017, 24, 26-32. doi: 10.5604/12321966.1233893.

57. Zygner W., Jaros S., Wędrychowicz H.: Prevalence of Babesia canis, Borrelia afzelii, and Anaplasma phagocytophilum infection in hard ticks removed from dogs in Warsaw (central Poland). Vet. Parasitol. 2008, 153, 139-142. doi: 10.1016/j.vetpar.2008.01.036

Corresponding author: Marta Demkowska-Kutrzepa, PhD, Akademicka 12, 20-033 Lublin, Poland; e-mail: marta.demkowska@up.lublin.pl 